\title{
SPRAVEDLNOST POHLEDEM FORENZNÍ PSYCHOLOGIE A MOŽNOSTI JEJÍHO MĚŘENÍ V ČESKÉM PROSTŘEDÍ
}

\author{
JAN JAROŠ, EVA HÖSCHLOVÁ
}

\begin{abstract}
Příspěvek vychází z diplomové práce jednoho z autorů obhájené na katedře psychologie Filozofické fakultě Univerzity Karlovy v roce 2019. Cílem je představení výzkumů z oblasti soudní psychologie, konkrétně výzkumů věnujících se vnímání spravedlnosti především $\mathrm{v}$ zákonem upravených rozhodovacích procesech. V tomto kontextu je pro absenci tuzemských zdrojủ věnována hlavní pozornost zahraničním výzkumům. Konečně, ambicí př́spěvku je též přispět k odborné debatě na toto téma v české psychologické obci. $\mathrm{V}$ rámci empirické části je představen nově vytvořený Dotazník vnímané spravedlnosti mediace (DVSM), jeho vývoj a omezení, se kterými se autoři vypořádávají odkazem na svou další výzkumnou činnost.
\end{abstract}

Klíčová slova: forenzní psychologie, spravedlnost, procedurální spravedlnost, soudní psychologie

Justice from the point of view of forensic psychology and the possibilities of its measurement in the Czech environment

\section{Abstract:}

This paper is based on the one of the author's diploma thesis defended at the Department of Psychology, Faculty of Arts, Charles University in 2019. The main objective is to present forensic psychology research, especially the research focused on the perception of justice in legally regulated decision-making procedures. Due to the absence of domestic sources, the main attention is focused on foreign research. Finally, it is the ambition of the presented paper to contribute to the professional discussion on the relevant topic within the Czech psychological community.

The empirical part presents the newly developed Questionnaire of Perceived Justice in Mediation (DVSM), it's creating stages and limitations. Also, another research activity of the authors is presented, in which the limitation of DVSM are addressed.

Keywords: forensic psychology, justice, procedural justice, legal psychology

https://doi.org/10.14712/23366486.2021.1

\section{1. Úvod}

V rámci tradičního dělení aplikovaných psychologických disciplín zastává mezi dalšími své pevné místo forenzní psychologie. Převažující obsah jejího zaměření v českém prostředí pak asi nejlépe vystihuje definice Č́rtkové $(2004$, s. 8), dle které „Forenzní psychologie je aplikovanou psychologickou disciplínou, která se zabývá chováním a prožíváním lidí v situacích regulovaných právem, především pak právem trestním." Onen dovětek týkající se speciálního zaměření na trestněprávní problematiku je pro tuzemskou forenzní 
psychologii pozoruhodně charakteristický. Byt' zejména v aktuální literatuře lze najít čestné výjimky (Boukalová \& Gillernová, 2020), v drtivé většině odborných publikací zaměřených tímto směrem je forenzní psychologie stále silně zaměřena především na trestněprávní problematiku a související psychologické aspekty, aniž by byly znatelněji reflektovány její další součásti, případně se jedná o publikace věnující se vymezení obecných zákonitostí psychologie a jejich funkcí v oblasti psychologie forenzní (Polišenská, 2019a). Přestože určité odůvodnění tohoto nahlížení oboru forenzní psychologie můžeme spatřovat $\mathrm{v}$ jeho historickém vývoji, kde $\mathrm{v}$ tuzemsku i zahraničí hrály otázky kriminologie a kriminalistiky výraznou roli (Polišenská, 2019b), je tento dodnes velmi koncentrovaný pohled pozoruhodný. $\mathrm{O}$ to pozoruhodnější, když většina autorů alespoň okrajově zmiňuje i další oblasti a sama prvně citovaná autorka při definici forenzní psychologie vychází z původního významu slova, forum" a odkazuje na jeho v tuzemsku údajně ujatý nepřesný překlad ,soudni psychologie“, či neujatý vhodnější překlad ,psychologie práv$n i^{\prime \prime \prime}$ (Č́rtková, 2004). Byt' se na základě stručné rešerše tuzemské literatury neodvažujeme tvrdit, že by se v České republice označení právní či soudní psychologie ujalo, je záměrem tohoto článku vnést právě soudní psychologii do obecného diskurzu odborné a zaujaté psychologické veřejnosti.

\section{Soudní psychologie a procedurální spravedlnost}

V souladu s označením ,soudni“ má předkládaný text za cíl nabídnout rozšíření dosud relativně úzkého pohledu na forenzní psychologii a pozvat psychologickou veřejnost po vzoru zahraničních kolegů $\mathrm{k}$ většímu zapojení do této bohaté oblasti aplikovaného výzkumu.

V následujícím textu bude často řeč o spravedlnosti, což je téma tuzemskou psychologií poněkud opomíjené. Především bude řeč o spravedlnosti před soudem a v dalších rozhodovacích procesech, což byla doména doposud opanovaná především filosofií a právní teorií. Nicméně k tématu spravedlnosti má už ze své podstaty mnohé co ř́ct také forenzní psychologie, jak má za cíl ukázat tento text.

Přestože zákonem upravené rozhodovací procesy nejsou v psychologii prozatím natolik populární jako výzkumy obecného lidského rozhodování z r̆ad laureátů Nobelovy ceny (Kahneman, 2013; Thaler \& Sunstein, 2010), jedná se o nepř́liš vzdálenou problematiku, jejíz praktické dopady mohou prímo ovlivnit nezanedbatelnou část populace, která během svého života získá zkušenost s některým z typů soudního řízení. Nebot' nehledě na skutečnost, zda se jedná o občanskoprávní konflikty, trestněprávní problematiku (Tyler, 2007), či specificky o alternativní způsoby řešení sporů (Kitzman \& Emery, 1993), z výzkumů soustavně vyplývá, že mimořádný vliv na vnímání spravedlnosti rozhodovacího procesu má kromě výsledného rozhodnutí též férovost procesu, kterým tohoto rozhodnutí bylo dosaženo (Sivasubramaniam \& Heuer, 2007; Tyler, 2007). Dokonce se ve výzkumech potvrzuje, že vnímaná férovost procesu předcházejícího konečnému rozhodnutí má na celkově vnímanou spravedlnost výrazně vyšší vliv, nežli vnímaná spravedlnost konečného rozhodnutí jako takového (Tyler, 2007). A právě zde, v otázce subjektivního prožívání pocitu spravedlnosti, se před námi otevírá mimořádný prostor pro rozvoj další ze subkategorií forenzní psychologie, psychologie soudní. V zahraničí je tato oblast již hustě zastoupena především pod praporcem tzv. procedurální spravedlnosti (procedural 
justice) a před tím, než se zde pokusíme usídlit též v české krajině, nabízí se jako žádoucí za hranicemi načerpat tolik inspirace, kolik jen je možné a začlenit tuzemský výzkum do kontextu v zahraničí již desítky let probíhajícího vědeckého rozpuku.

\section{Vývoj a současný stav poznání na poli procedurální spravedlnosti}

Za hranicemi České republiky je vědecký výzkum spravedlnosti a jeho praktická aplikace součástí odborné diskuze od 60. let 20. století. A přestože ve společenskovědních oborech může být obtížné přiřknout autorství původní teorie jednomu objeviteli, když myšlenky mají tendenci se opakovat a vycházet jedna z druhé, identifikujeme počátky psychologického výzkumu v oblasti spravedlnosti v Adamsově (1963) teorii tzv. distributivní spravedlnosti. A to i přesto, že sám Adams toto prvenství připisuje v podobě konkrétní teorie Homansovi (1961), a v podobě prapůvodního konceptu, jak tomu ve společenských vědách bývá, jednomu z tradičně citovaných antických myslitelů, Aristotelovi (Adams, 1965). Nicméně aniž bychom na kteréhokoli z uvedené dvojice (Aristoteles promine) museli kvůli původcovství ukazovat prstem, zásadní je, že od poloviny minulého století se zahraniční psychologie zamýšlí nad skutečností, že nehledě na charakter vztahu, tj. at' se jedná o manžele, kolegy v zaměstnání, či spoluhráče, kdykoli dochází k výměně či rozdělování zdrojů mezi dvěma a více lidmi, existuje zde reálná možnost, že minimálně jeden ze zúčastněných bude takovou situaci subjektivně vnímat jako nespravedlivou (Adams, 1963). Nebot' dle Adamse (1963, s. 424) „Nespravedlnost existuje, kdykoli člověk vnímá své pracovní výdaje a prŕnosy v psychologicky averzním vztahu oproti tomu, co vnímá jako výdaje a př́nosy ostatních.““

V dalších podrobnostech mnohaletého vývoje je možné odkázat na diplomovou práci jednoho z autorů (Jaroš, 2019), přičemž pro účely tohoto textu lze jako další zásadní milník na psychologickém poli spravedlnosti zmínit 80 . léta 20. století a posun od výzkumu čistě distributivní spravedlnosti, tj. spravedlnosti konečného rozhodnutí o rozdělení práv a statků, k tzv. spravedlnosti procedurální, neboli spravedlnosti procesu, který konečnému rozhodnutí předchází (Leventhal, 1980; Thibaut \& Walker, 1975). Nebot’ téměřr okamžitě po ukotvení teorie distributivní si v druhé polovině 20. století začali relevantní autoři (Deutsch, 1975, 1985; Leventhal, 1980; Thibaut \& Walker, 1975) stále častěji klást otázku, zda to je pouze konečné rozhodnutí, které ovlivňuje naše subjektivní usuzování o spravedlnosti. A stále častěji zaznívala odpověd', že nikoli. Tedy že koncept spravedlnosti distributivní, přestože správný, je nadále nedostačující a musí být rozšířen (Deutsch, 1975, 1985; Leventhal, 1980). K tomuto rozšíření pak došlo především ve dvou oblastech, a sice v tomto textu tolik akcentované oblasti psychologie soudní (Lind \& Tyler, 1988; Tyler, 1989, 2000) a paradoxně pro účely tvorby měřicích nástrojů zřejmě významnější oblasti psychologie práce a organizace (Cohen-Charash \& Spector 2001; Colquitt, 2001; Greenberg, 1987, 1988, 1990).

Za rozvoj soudní psychologie vděčíme v zahraničí především Tylerovi (Lind \& Tyler, 1988; Tyler, 1989, 2000, 2007). Výsledkem jeho mnohaleté výzkumné práce je kromě jiného identifikace čtyř základních faktorů určujících vnímání spravedlnosti. Těmito jsou (i) „voice“ neboli možnost vyjádřit vlastní názor a pocity ve vztahu k dané situaci,

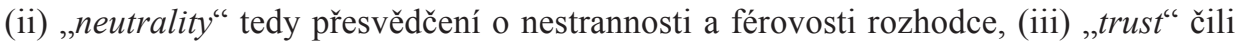
důvěra reprezentovaná vírou v upřímnost, starost a opravdový zájem ze strany rozhodce, 
a konečně (iv) ,respect“ ze strany rozhodce ke sporným stranám v průběhu celého procesu (Tyler, 2007). V otázce, jak tyto faktory identifikovat a měřit jejich význam, se opět dostává ke slovu právě soudní psychologie. Vedle Tylera (1989, 2000, 2007), který se výzkumně věnoval jak sporům odehrávajícím se čistě před soudem, tak i oblasti alternativního řešení konfliktů, a který svou pozornost v poslední dekádě v oblasti procedurální spravedlnosti s výjimkami (Rottman \& Tyller, 2014) přesunul do oblasti trestního procesu a policejní ćinnosti (Meares et al. 2016; Trinker et al., 2016; Tyler 2017a, 2017b; Tyler et al., 2015), realizovali v oblasti soudní psychologie své výzkumy i další odborníci, kteří se však primárně zaměřovali na vnímání spravedlnosti v méně formalizovaných procesech rozhodčího řízení (Lind et al. 1993) či ještě více neformálním procesu mediace (De Girolamo, 2019; Pruitt et al., 1993), ba dokonce v procesu dvoustranného vyjednávání (Hollander-Blumoff, 2017; Hollander-Blumoff \& Tyler, 2008). Uvedenému trendu kromě jiného napomohl zřejmě také fakt, který Tyler (2000, s. 121) shrnuje v konstatování: „Ve skutečnosti $\mathrm{v}$ občanskoprávních sporech hodnotí sporné strany mediaci jako férovější než formální soudní řízení, a typicky je také hodnocena jako více uspokojující.“ Že soudní psychologie má v zákonem upravených způsobech rozhodování své místo, potvrzují Hollander-Blumhoff a Tyler (2008, s. 473) i v další ze svých studií, dle které „Výsledky naznačují, že procedurální spravedlnost podporuje akceptaci ujednaných dohod, stejně jako vede k rozvoji integrativního vyjednávání.“

Už bylo zmíněno, že $v$ rozvoji vnímané spravedlnosti, a především v otázce jejího měření hrála vedle soudní psychologie významnou úlohu též sousední disciplína psychologie práce a organizace. Greenbergem (1987) počínaje se v následujících letech vedla intenzivní diskuze o konceptu tzv. organizační spravedlnosti, kterou chápeme jako vnímanou spravedlnost rozhodovacích procesů a jejich výsledků v pracovním prostředí. V tomto smyslu Greenberg $(1987,1988,1990)$ zastával pohled dvoudimenzionálního modelu organizační spravedlnosti skládajícího se z dimenze spravedlnosti procedurální a distributivní. Zatímco na stranu této koncepce se připojili i další autoří, např́klad Sweeney a McFarlin (1993) do opozice s komplikovanějším tř́dimenzionálním modelem se postavili kupríkladu Mikula et al. (1990, s. 133), kteří ve své studii poukazují, že ,je pozoruhodné, že značný podíl nespravedlnosti, která byla ohlášena, se netýkal distributivních nebo procedurálních témat $\mathrm{v}$ užším slova smyslu, nýbrž odkazoval na způsob jednání, jakým s lidmi bylo zacházeno v mezilidských interakcích a setkáních,“a navazují tak na Biese a Moaga (1896), kteří jako první identifikovali a pojmenovali tuto třetí tzv. interakční dimenzi spravedlnosti. Své zastánce si konečně našly oba názorové proudy (Barling \& Phillips, 1993; Niehoff \& Moorman, 1993). Nicméně byl to opět Greenberg (1993), kdo debatu o metodice výzkumu organizační spravedlnosti posunul o další vývojový stupeň a představil svou čtyřdimenzionální strukturu vnímané spravedlnosti v organizacích. Uvedený odborný rozpor $\mathrm{v}$ této oblasti přetrval i nadále a na počátku nového tisíciletí jej reprezentují dvě zásadní metaanalýzy. Colquitt (2001) se na jednu stranu ve své metastudii přiklání ke čtyřdimenzionálnímu modelu organizační spravedlnosti, tj. modelu dimenzí spravedlnosti procedurální, distributivní, interpersonální a informační, zatímco autorské duo Cohen-Charash a Spector (2001) se v rámci své metaanalýzy staví na stranu tř́́dimenzionálního modelu spravedlnosti distributivní, procedurální a interakční. Konečně co z jednoho úhlu pohledu je možné nahlížet jako odborný konflikt, se z jiné perspektivy může jevit jako živá a plodná diskuze odborné veřejnosti na aktuální a zásadní téma. Neboli, jak v závěru své metaanalýzy uvádějí Cohen-Charash se Spectorem (2001, 
s. 310): „Tyto rozdíly v konceptualizaci [organizační] spravedlnosti nabízejí čtenáři jedinečnou př́ležitost porovnat a posoudit tutéž otázku ze dvou perspektiv.“

Praktickým výsledkem výše stručně shrnutých 60 let aplikovaného výzkumu a vědecké práce jsou dnes především ve Spojených státech snahy o monitorování vnímané spravedlnosti soudních a alternativních způsobů rozhodování (2017 Court Access \& Fairness Survey Report, 2017; Access and Fairness, 2005) v každodenním fungování justičního systému. Tato pro veřejnost zásadní měření probíhají v různých podobách, a kromě jiného představovala motivaci pro níže popsaný výzkum.

\section{Autorský příspěvek $k$ tuzemskému výzkumu procedurální spravedlnosti}

V úvodu deklarovaným cílem tohoto textu je podnícení odborné diskuze a pozvání k zvýšenému zájmu o obor soudní psychologie v kontextu vnímané spravedlnosti. A tak zatímco $\mathrm{v}$ předchozí kapitole byla tato oblast čtenáři z řad zaujaté veřejnosti představena skrze zahraniční výzkumy, tato kapitola má za cíl představit první a navazující kroky autorů z této oblasti v tuzemsku. Vủbec prvním krokem byl diplomový výzkum jednoho $\mathrm{z}$ autorů realizovaný $\mathrm{v}$ oblasti vnímané spravedlnosti mediačního řizení. Jedním z výstupů tohoto výzkumu byl kvalitní prototyp prvního tuzemského postojového dotazníku vnímané spravedlnosti mediačního řizení. Dalším postupem, kterým autoři tohoto textu následují vlastní výzvy k hojnějšímu zájmu o uvedené téma, je probíhající volně navazující výzkum souvisejícího tématu Vnímané spravedlnosti soudních rozhodnutí realizovaný s podporou Grantové agentury Univerzity Karlovy.

\subsection{RELEVANTNÍ CÍL VÝZKUMU VNÍMANÉ SPRAVEDLNOSTI}

Zatímco za hranicemi České republiky je vnímané spravedlnosti a alternativním způsobům řešení konfliktů věnována patřičná pozornost, v tuzemsku tomu tak prozatím není. Až v roce 2012 byla do českého právního řádu zakotvena mediace jako alternativní forma řešení konfliktů s cílem znatelně odlehčit jinak přetíženým soudům (Důvodová zpráva k zákonu o mediaci, 2011). Protože se tak zřejmě nestalo, byt' tento závěr je možné opírat pouze o neoficiální zdroje z mediačního prostředí a v zásadě konstantní statistiky soudních řízení (Ministerstvo spravedlnosti ČR, 2018), bylo by přirozené systematicky prověřit důvody takového vývoje. Tímto směrem zaměřil pozornost i předkládaný výzkum. Cílem diplomového výzkumu bylo ověřit rozdíly ve vnímané spravedlnosti mediačního procesu mezi dotčenými subjekty, tj. (i) soudci, kteří mediaci účastníkům konfliktu mohou v určitém smyslu nařídit či doporučit; (ii) advokáty, kteří své klienty při mediaci zastupují (a zároveň jako formu řešení jejich konfliktu doporučují či rozmlouvají); (iii) mediátory jakožto vykonavateli procesu, o kterém je řeč; a (iv) veřejností, jejíž názor vytváŕí společenský kontext, v němž se celý systém nachází. Výsledky tohoto výzkumu měly posloužit jako odrazový můstek k prozkoumání pravdivosti dosud v tuzemsku tvrzených (Důvodová zpráva k zákonu o mediaci, 2011), nicméně po vzoru zahraničí (Emery et al., 2001; Tyler, 2000;) stále empiricky neověřených výhod mediace spočívajících například v rychlosti, kultivovanosti a celkově pozitivním naladění celého mediačního procesu (Důvodová zpráva k zákonu o mediaci, 2011). 
Uvedeného cíle však nešlo dosáhnout bez toho, aniž by byl k dispozici kvalitní měřicí nástroj z oblasti soudní psychologie, tj. postojový dotazník vnímané spravedlnosti mediace, který v tuzemsku v dané době neexistoval. Pro účely diplomového výzkumu tak byl první prototyp po vzoru zahraničních nástrojů vytvořen a jeho představení, jakož i detailní popis vývoje a vzniku představují jeden z hlavních účelů tohoto textu.

\subsection{PŘíPRAVNÁ ČÁST TVORBY DOTAZNÍKU VNÍMANÉ SPRAVEDLNOSTI MEDIACE (DVSM)}

Přípravná fáze dotazníku sestávala z podrobné rešerše tuzemských zdrojů a oslovení dotčených institucí s dotazem na těmito realizované či zadávané relevantní výzkumy. Protože od žádného z dotázaných subjektů nepř̌išla pozitivní odezva a lepší výsledky nepřinesla ani rešerše domácí literatury, byla pozornost obrácena do zahraničí. Postupným

Tabulka 1 Položky Dotazniku vnímané spravedlnosti mediace

1. Při mediaci se pracuje s přesnými informacemi.

2. Mediátor k účastníkům mediace přistupuje s respektem.

3. Mediace je časově efektivní způsob řešení konfliktu.

4. Mediátor před žádným z účastníků nezatajuje informace důležité pro průběh mediace.

5. Mediace bývá ovlivněna předsudky mediátora.

6. Smyslem mediace je vést účastníky ke smírnému řešení jejich konfliktu.

7. Mediátor má detailní znalost předmětu sporu účastníků mediace.

8. Po ukončené mediaci je možné mít s druhým účastníkem mediace dobré vztahy.

9. Mediátor není během mediace při komunikaci s účastníky upř́mný.

10. Výsledek mediace je pro jednoho z účastníků výhodnější.

11. V průběhu mediace mají účastníci dostatečný prostor $\mathrm{k}$ vyjádření svých pocitů.

12. Mediátor má dostatečnou kvalifikaci, aby účastníkům pomohl s vyřešením jejich sporu.

13. Při mediaci má účastník možnost říct vše, co potřebuje.

14. Mediátor se během mediace zdržuje nevhodných poznámek a komentářů.

15. V průběhu mediace se dodržují etické a morální standardy.

16. Mediátor přizpůsobuje formu své komunikace potřebám účastníků.

17. Vztahy účastníků jsou po ukončení mediace lepší než na jejím počátku.

18. Mediátor informuje účastníky o zásadních informacích bezodkladně.

19. Účastníci mediace zásadním způsobem ovlivňují její výsledek.

20. Mediátor účastníky mediace detailně seznámí s jejím průběhem.

21. Smyslem mediace je urovnat poškozené vztahy mezi účastníky.

22. Mediátor se k účastníkům mediace chová př́ivětivě.

23. Velmi poškozené vztahy mezi účastníky už mediace nemůže napravit

24. Mediace není zkreslena straněním jednomu z účastníků.

25. S výsledkem mediace mohou být spokojeni oba účastníci.

26. Mediátor je schopen potlačit své osobní sympatie k některému z účastníků mediace.

27. Výsledek mediace odpovídá úsilí, které do předmětu sporu vložil každý z účastníků.

28. Je v zájmu mediátora prodlužovat délku mediačního procesu. 
procesem trrídění relevantních studií byl jejich počet z původních několika desítek zúžen na jednotky. I přesto se však následně po odpovídající úvaze nejevilo jako vhodné žádný ze zahraničních dotazníků bez dalších úprav využít. Hlavním důvodem byla skutečnost, že většina z nich byla koncipována ve vztahu ke konkrétnímu rozhodovacímu procesu, zatímco vznikající dotazník byl plánován jako obecný postojový měřicí nástroj. Zahraniční výzkumy (Bies \& Moag, 1986; Leventhal, 1976; Shapiro et al., 1994; Thibaut \& Walker, 1975), které v metaanalýzy pro naše účely užitečnou formou seskupil Colquitt (2001), tak posloužily především jako ideový základ pro sestavení osmadvaceti položkového dotazníku vnímané spravedlnosti mediace (DVSM) nově vznikajícího speciálně pro české prostředí.

\subsection{VÝZKUMNÝ SOUBOR}

V rámci výzkumu bylo prostřednictvím elektronického dotazníku v on-line i off-line verzi osloveno 115 účastníků na základě př́ležitostného výběru a dobrovolnosti. Deskriptivní statistika i testové metody byly následně realizovány na výzkumném vzorku 112 respondentů $(\mathrm{N}=112)$, když 3 respondenti byli kvůli chybějícím či nesmyslným hodnotám ze vzorku vyřazeni. Celkově ve výzkumném souboru převládaly ženy $(\mathrm{N}=71$; $63,4 \%)$ nad muži $(\mathrm{N}=41,36,6 \%)$ a průměrný věk respondentů činil 35,9 let se směrodatnou odchylkou 9 roků.

\subsection{PROCEDURA}

Sběr dat byl realizován v průběhu června a července 2019. Skrze sociální sítě bylo osloveno přibližně 9000 advokátů a advokátních koncipientů. V součinnosti s Justiční akademií ČR bylo osloveno řádově několik stovek soudkyn̆ a soudců, a konečně př́ímo jedním z autorů bylo adresně osloveno, či byl alespoň učiněn odpovídající pokus

Tabulka 2 Podrobná charakteristika výzkumného souboru

\begin{tabular}{|c|c|c|c|c|c|c|}
\hline & $\begin{array}{l}\check{Z}=\text { Žena } \\
\mathbf{M}=\text { Muž }\end{array}$ & Počet & $\begin{array}{l}\text { Věkový } \\
\text { průměr }\end{array}$ & SD & Modus & Min-Max \\
\hline $\begin{array}{l}\text { Výzkumný } \\
\text { vzorek celkem }\end{array}$ & $\begin{array}{l}\check{Z} \\
\mathrm{M}\end{array}$ & $\begin{array}{l}71 \\
41\end{array}$ & $\begin{array}{l}35,7 \\
37,3\end{array}$ & $\begin{array}{l}9,23 \\
8,52\end{array}$ & $\begin{array}{l}30 \\
31\end{array}$ & $\begin{array}{l}22-63 \\
27-59\end{array}$ \\
\hline Koncipient & $\begin{array}{l}\check{Z} \\
\mathrm{M}\end{array}$ & $\begin{array}{r}11 \\
5\end{array}$ & $\begin{array}{l}28,0 \\
33,4\end{array}$ & $\begin{array}{l}3,07 \\
8,88\end{array}$ & $\begin{array}{l}25^{*} \\
31\end{array}$ & $\begin{array}{l}25-35 \\
27-49\end{array}$ \\
\hline Advokát & $\begin{array}{l}\check{Z} \\
\mathrm{M}\end{array}$ & $\begin{array}{l}18 \\
11\end{array}$ & $\begin{array}{l}32,3 \\
34,1\end{array}$ & $\begin{array}{l}5,33 \\
8,89\end{array}$ & $\begin{array}{l}28^{*} \\
30\end{array}$ & $\begin{array}{l}28-47 \\
28-59\end{array}$ \\
\hline Mediátor & $\begin{array}{l}\text { Ž } \\
M\end{array}$ & $\begin{array}{r}13 \\
5\end{array}$ & $\begin{array}{l}43,2 \\
40,0\end{array}$ & $\begin{array}{l}9,92 \\
4,18\end{array}$ & $\begin{array}{l}48^{*} \\
34^{*}\end{array}$ & $\begin{array}{l}26-45 \\
34-63\end{array}$ \\
\hline Mediátor/Advokát & $\begin{array}{l}\check{Z} \\
\mathrm{M}\end{array}$ & $\begin{array}{l}6 \\
6\end{array}$ & $\begin{array}{l}45,5 \\
40,8\end{array}$ & $\begin{array}{r}5,39 \\
10,10\end{array}$ & $\begin{array}{l}39^{*} \\
30^{*}\end{array}$ & $\begin{array}{l}39-54 \\
30-55\end{array}$ \\
\hline Soudce & $\begin{array}{l}\text { Ž } \\
M\end{array}$ & $\begin{array}{l}9 \\
7\end{array}$ & $\begin{array}{l}38,1 \\
39,1\end{array}$ & $\begin{array}{l}8,93 \\
7,74\end{array}$ & $\begin{array}{l}27 * \\
44\end{array}$ & $\begin{array}{l}27-52 \\
27-47\end{array}$ \\
\hline Veřejnost & $\begin{array}{l}\check{Z} \\
\mathrm{M}\end{array}$ & $\begin{array}{r}16 \\
5\end{array}$ & $\begin{array}{l}31,3 \\
38,0\end{array}$ & $\begin{array}{r}8,84 \\
10,10\end{array}$ & $\begin{array}{l}30 \\
30 *\end{array}$ & $\begin{array}{l}22-50 \\
30-54\end{array}$ \\
\hline
\end{tabular}

* Existuje více než jeden modus, reportován byl pouze první. 
o oslovení, všech 258 zapsaných mediátorek a mediátorů v té době vedených v seznamu mediátorů Ministerstva spravedlnosti České republiky.

\subsection{ANALYTICKÁ ČÁST TVORBY DVSM - POLOŽKOVÁ ANALÝZA A RELIABILITA}

Na sebraných a uspořádaných datech od $(\mathrm{N}=112)$ respondentů byla provedena položková analýza klasické teorie testů. Zjišt'ovány byly v rámci výpočtu s hrubými skóry položek hodnoty průměru, obtížnosti, směrodatné odchylky, korelace s celkovým hrubým skóre a dílčími hrubými skóre jednotlivých čtyř předpokládaných dimenzí procedurální, distributivní, interakční a informační spravedlnosti. Až na položku č. 6 s hodnotou obtížnosti 0,93 se hodnoty všech položek pohybovaly v rozsahu od 0,50 do 0,87 , a splňovaly tak předem stanovené rozpětí obtížnosti 0,1 až 0,9 . Reliabilita nově vytvořeného dotazníku byla hodnocena odhadem vnitřní konzistence testu pomocí Cronbachovo alfa $(\alpha=0,92)$.

V návaznosti na položkovou analýzu byla provedena také mezipoložková korelace za využití Spearmanova korelačního koeficientu, přičemž mezi jednotlivými položkami byly až na výjimečné případy zjištěny spíše střední hodnoty vzájemné korelace pod hranicí $r=0,6$ a průměrná mezipoložková korelace $r_{a v g}=0,35$.

\subsection{ANALYTICKÁ ČÁST TVORBY DVSM - FAKTOROVÁ ANALÝZA}

Vzhledem k prostudovaným zdrojům a neskončené odborné diskuzi o dimenzích tvořících výsledný subjektivní dojem spravedlnosti rozhodovacího procesu a jeho výsledku bylo záměrem ověřit v nově vznikajícím dotazníku jeho strukturu. Otázka stála, zda bude dotazník vykazovat existenci čtyř hlavních dimenzí, jako tomu bylo u ideové předlohy (Colquitt, 2001), nebo zda bude převažovat jiná latentní struktura. V rámci obsahové analýzy byly do dotazníku zahrnuty položky z kategorie procedurální spravedlnosti, distributivní spravedlnosti, interakční spravedlnosti a informační spravedlnosti. Pro zjišt'ování faktorové struktury nového dotazníku byla využita exploratorní faktorová analýza (EFA).

V provedených variantách explorativní faktorové analýzy Kaise-Meyer-Olkin test přesáhl doporučovanou hladinu 0,8 i v Batlettově testu sféricity bylo dosaženo pozorované hladiny významnosti $(p<0,001)$. Dle těchto výsledků lze tvrdit, že všechny korelační vztahy zkoumaných dat byly na požadované úrovni těsnosti a data jsou vhodná pro faktorovou extrakci.

První zvolenou metodou faktorové extrakce byla metoda Principal axis factoring (PAF) s rotací faktorové matice metodou Varimax a Kaiserovou normalizací. Výsledkem tohoto postupu byla identifikace jednoho zásadního faktoru s vlastním číslem 10,25 vysvětlujícího 37,960 \% variance položek. Celkově PAF generovala šest faktorů s vlastním číslem

Tabulka 3 Míry KMO a Bartlettův test sféricity

\begin{tabular}{|l|l|l|}
\hline \multicolumn{2}{|l|}{ Kaiser-Meyer-Olkin } & 0,855 \\
\hline \multirow{3}{*}{ Bartlettův test sféricity } & Bartlett. Chí-kvadrát & 1649,552 \\
\cline { 2 - 3 } & Stupně volnosti & 351 \\
\cline { 2 - 3 } & $p$ & $<0,001$ \\
\hline
\end{tabular}


Tabulka 4 Vysvětlení variance v rámci EFA (extrakce pomoci Principal Axis Factoring)

\begin{tabular}{|c|c|c|c|c|c|c|}
\hline \multirow{2}{*}{ Faktor } & \multicolumn{3}{|c|}{ Nerotované řešení } & \multicolumn{3}{c|}{ Rotace Varimax } \\
\cline { 2 - 7 } & $\begin{array}{c}\text { Vlastní } \\
\text { číslo }\end{array}$ & $\begin{array}{c}\% \\
\text { variance }\end{array}$ & $\begin{array}{c}\text { Kumulativní } \\
\%\end{array}$ & $\begin{array}{c}\text { Vlastní } \\
\text { číslo }\end{array}$ & $\begin{array}{c}\% \\
\text { variance }\end{array}$ & $\begin{array}{c}\text { Kumulativní } \\
\%\end{array}$ \\
\hline 1 & 10,249 & 37,960 & 37,960 & 9,840 & 36,443 & 36,443 \\
\hline 2 & 1,725 & 6,390 & 44,350 & 1,256 & 4,652 & 41,095 \\
\hline 3 & 1,556 & 5,763 & 50,113 & 1,082 & 4,007 & 45,102 \\
\hline 4 & 1,437 & 5,321 & 55,435 & 0,970 & 3,594 & 48,696 \\
\hline 5 & 1,281 & 4,745 & 60,180 & 0,813 & 3,011 & 51,707 \\
\hline 6 & 1,133 & 4,198 & 64,377 & 0,690 & 2,555 & 54,261 \\
\hline 7 & 0,980 & 3,628 & 68,006 & & & \\
\hline 8 & 0,864 & 3,199 & 71,205 & & & \\
\hline 9 & 0,814 & 3,016 & 74,221 & & & \\
\hline 10 & 0,757 & 2,802 & 77,023 & & & \\
\hline$\ldots$ tabulka zkrácená na hodnoty prvních deseti faktoru &
\end{tabular}

vyšším než jedna a kumulativně vysvětlujících 64,38 \% variance. Nicméně i přestože zbylých pět faktorů z nabízeného šestifaktorového rozdělení mělo vlastní číslo vyšší jedné, oproti prvnímu faktoru se jednalo o prakticky zanedbatelné hodnoty, což ostatně potvrzuje i znázornění sutinového grafu v Obrázku 1 níže.

Postupně byly explorovány také dvoufaktorové, tř́faktorové i čtyřfaktorové modely s obměnami kritérií rotace faktorů. Zjištěné výsledky (vysvětlená variabilita, míra

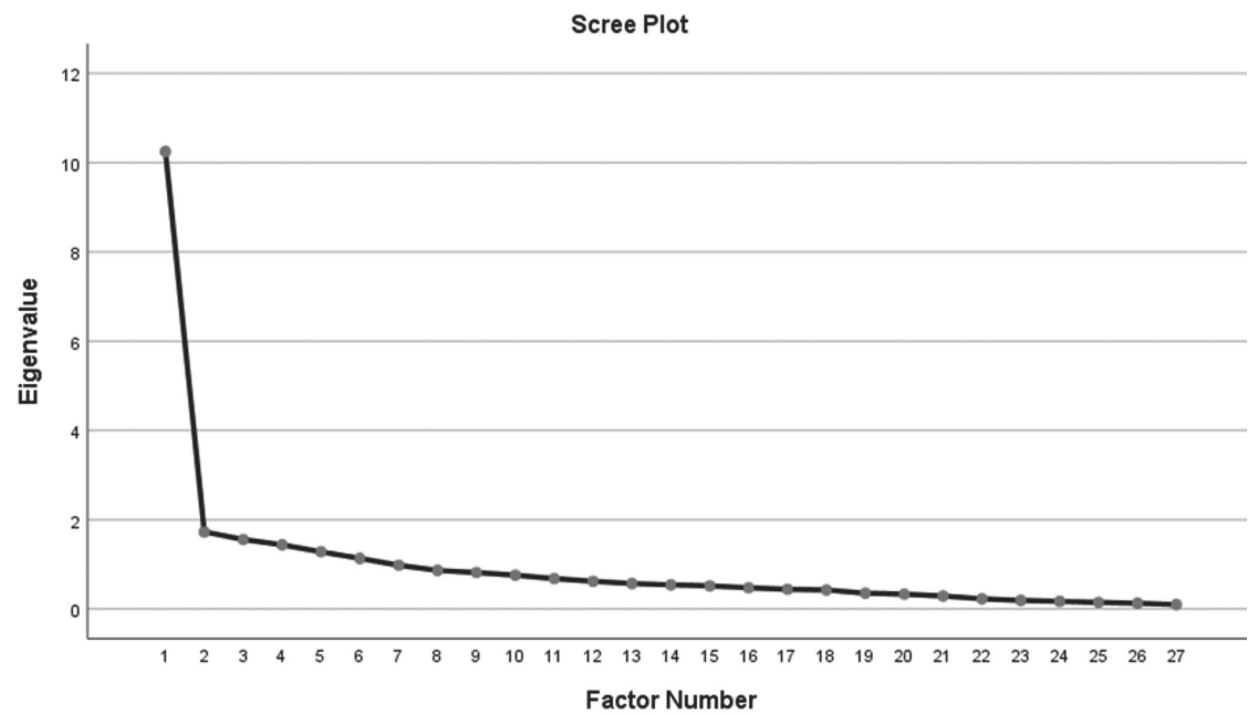

Obrázek 1 Sutinový graf (scree plot) znázorňujicí vlastní čísla faktorů 
cross-loadingů, velikost loadingů) ovšem naznačovaly, že jednofaktorové řešení je pro sebraná data nejvíce odpovídající.

\subsection{ZKRÁCENÉ VERZE DVSM4 A DVSM8}

Jedním z výsledků diplomového výzkumu prezentovaného v tomto článku je nově vytvořený prototyp Dotazníku vnímané spravedlnosti mediačního řízení (DVSM), který se ukázal být vnitřně konzistentním měřicím nástrojem vnímané spravedlnosti sestaveným z položek odpovídající kvality. Výsledky položkové analýzy také ukazovaly na velmi vysoké korelace některých položek s celkovým hrubým skóre dotazníku vnímané spravedlnosti mediace (DVSM). Rozhodli jsme se proto vytvořit také kratší verze původního dotazníku, které by i při výrazné redukci původního počtu položek mohly sloužit k měření vnímané spravedlnosti mediace s podobnou přesností jako osmadvaceti položkový originál. Nejkratší, čtyřpoložková verze dotazníku DVSM4 zahrnující položky č. 10 ,, Výsledek mediace je pro jednoho z účastniků výhodnější. “, č. 14 „,Mediátor se během mediace zdržuje nevhodných poznámek a komentář̀u, “ ‘̌. 15 ,,V průběhu mediace se dodržují etické a morální standardy, “ a č. 16 „,Mediátor přizpiosobuje formu své komunikace potřebám účastníkü, “ dosahuje velmi vysoké korelace s celkovým skóre původní plné verze $(r=0,90)$ a relativně dobrých výsledků vnitřní konzistence počítané pomocí Cronbachova alfa $(\alpha=0,8)$. Pro střední, osmipoložkovou variantu DVSM8, která byla oproti nejkratší verzi rozšířena o položky č. 13 „Při mediaci má účastník možnost řict vše, co potrebuje, “ č. 17 „,Vztahy účastníkủ jsou po ukončení mediace lepší než na jejím počátku, “ č. 18 „,Mediátor informuje účastníky o zásadních informacích bezodkladně, “ a č. 27 ,,Výsledek mediace odpovidá úsilí, které do předmětu sporu vložil každý z účastníků, “ byla korelace s celkovým skóre plné verze dotazníku ještě o něco vyšší $(r=0,93)$, stejně jako hodnota vnitřní konzistence $(\alpha=0,87)$.

\section{Diskuze}

Hlavním cílem empirické části této studie bylo na základě důkladné rešerše z oblasti spravedlnosti a jejího měření vytvořit kvalitní český nástroj na zachycení vnímané spravedlnosti v oblasti mediace. Pilotní studie ukázala, že vytvořený nástroj DVSM se sestává ze setu položek odpovídajících standardním požadavkům klasické položkové analýzy a že je nástrojem vnitřně konzistentním a v tomto ohledu reliabilním. Explorační faktorová analýza ukázala spíše na jednofaktorový základ vytvořené metody, což je odlišné od dvoufaktorových (Greenberg 1990; Sweeney \& McFarlin, 1993) a čtyřfaktorových (Colquitt, 2001) pojetí spravedlnosti. Možným důvodem této odlišnosti může být skutečnost, že na rozdíl od výše citovaných studií se v prrípadě popisovaného výzkumu jednalo o data získaná z postojového dotazníku, kdy by bylo smysluplné, aby v př́padě pozitivního postoje k mediaci skórovali respondenti vysoce ve všech škálách, zatímco respondenti vyplňující obdobné dotazníky týkající se vnímané spravedlnosti ve vztahu ke konkrétnímu procesu mohou být ve svých odpovědích výrazně konkrétnější, a tudíž daleko více nevyrovnaní. Kromě toho je nezbytné nezapomínat, že ohledně složek, dimenzí či faktorů spravedlnosti se v posledních třiceti letech (Bies \& Moag, 1986) vede mezi odbornou veřejností velmi intenzivní debata. Nicméně i po letech diskuzí mezi názorovými zastánci 
jednofaktorového (Cropanzano \& Ambrose, 2001), dvoufaktorového (Sweeney \& McFarlin, 1993), třífaktorového tábora (Ambrose et al., 2002; Bies, 2005; Cohen-Charash \& Spector, 2001) či čtyřfaktorového názorového proudu (Colquitt, 2001; Karnan \& Hanges, 2002) stále není konsensus. Tato neshoda pramení především z odlišného náhledu jednotlivých výzkumníků na skutečnost, zda interakční (Bies, 2005), interpersonální či informační (Colquitt et al., 2001) a další složky spravedlnosti jsou samostatně stojícími faktory na úrovni faktoru distributivní a procedurální spravedlnosti, nebo zda jsou toliko součástí faktoru spravedlnosti procedurální.

Kromě postojové charakteristiky dotazníku je nutno mezi limity zmínit také jeho původní délku, čítající kromě šesti demografických i dalších padesát šest výzkumných položek. K tomu je nutno dodat, že tohoto limitu si autor byl v původní práci vědom, a přesto se rozhodl takto postupovat za účelem nashromáždění maximálního možného množství doposud v tuzemsku neznámých dat pro účely jejich dalšího zpracování. Zároveň je $\mathrm{v}$ tomto kontextu nutno vzpomenout $\mathrm{z}$ výzkumu vzešlé zkrácené verze dotazníku DVSM4 a DVSM8, které tento limit do budoucna odstraňují při zachování velmi dobrých psychometrických kvalit, čehož bude využito v dalších výzkumech autorského týmu. Současně se zmínkou zkrácených verzí dotazníku je nutno zejména u dotazníku DVSM4 neopomenout hraniční hodnoty Spearman-Brownova koeficientu split-half reliability $0,7(r=0,7)$. Autoři si jsou této skutečnosti vědomi a vzhledem $\mathrm{k}$ mimořádné stručnosti dotazníku čítajícího pouze čtyři výzkumné položky, jakož i s přihlédnutím $\mathrm{k}$ dobrému výsledku odhadu vnitřní konzistence Cronbachovo alfa $0,8(\alpha=0,8)$ považují hodnoty reliability dotazníku za relativně dobré a přijatelné zejména pro výzkumné účely. Dotazník lze v tomto kontextu využívat jakožto rychlý a orientační nástroj pro posouzení vnímané spravedlnosti mediace, přičemž jako nejvhodnější se mezi plnou verzí dotazníku a nejkratší čtyřpoložkovou verzí jeví využití střední, osmipoložkové verze, zachovávající si pozitivní vlastnosti obou předchozích, tj. velmi dobré psychometrické kvality a uživatelsky nenáročnou délku.

Další omezení výzkumu mohou dále vyplývat ze samotného složení výzkumného souboru. S ohledem na př́ležitostný a na dobrovolnosti založený sběr dat lze usuzovat na účast a priori výrazně vyhraněných respondentů, at' již pozitivně, či negativně, a lze tak obtižně zobecňovat na celou populaci. Významným omezením může být taktéž nízký počet respondentů $(\mathrm{N}=112)$, kterýžto je však nutno nahlížet z pohledu profesního složení respondentů, což výsledný počet do jisté míry relativizuje. Kromě velikosti vzorku pak může být na první pohled limitem výzkumu také jeho složení, když ve výzkumném souboru znatelně převládaly ženy $(\mathrm{N}=71 ; 63,4 \%)$ nad muži $(\mathrm{N}=41 ; 36,6 \%)$, což s přihlédnutím k posledním veřejně dostupným datům Českého statistického úrúadu o sčitání lidu v roce 2011 neodpovídá normálnímu rozložení pohlaví v populaci, kde toto je přibližně rovnoměrné v zastoupení 5109766 mužů a 5326794 žen (Český statistický úr̆ad, 2011). Na druhou stranu, z celkového počtu 258 tzv. zapsaných mediátorů, kteří byli oslovováni, bylo 56 mužů $(21,7 \%)$ a $202(78,3 \%)$ žen (Ministerstvo spravedlnosti ČR, 2019). Ve skupině advokátů a advokátních koncipientů je rozložení dle posledních údajů České advokátní komory taktéž nerovnoměrné, nicméně tentokrát ve prospěch mužů advokátů a advokátních koncipientů reprezentujících $60 \%$ všech členů komory ponechávajíc ženám advokátkám a advokátním koncipientkám zbylých 40 \% (Česká advokátní komora, 2005), proto ještě tématu vlivu pohlaví na výsledky dotazníku bude věnována pozornost $\mathrm{v}$ dalších studiích na větších vzorcích. Konečně, ve vztahu k výzkumnému souboru by posledním limitem 
mohl být průměrný věk respondentů 35,9 let. Nejmladšímu respondentovi, který se výzkumu účastnil, bylo 22 let, nejstaršímu 63 a modus věku výzkumného souboru byl 30 let.

Poslední zásadní limitace dotazníku představuje též jednu z hlavních motivací jeho tvorby. Touto je absence obdobných empirických studí́ tohoto typu v České republice, což na jednu stranu prezentuje jedinečnou výzkumnou možnost, současně však nelze pochopitelně využít obdobných tuzemských studií ke komparaci dosažených výstupů.

$\mathrm{V}$ rámci dalších studií a publikačních výstupů se bude autorská dvojice věnovat také tématu vnímané spravedlnosti soudního řízení celkově (opět postojový dotazník). Vycházet bude z téměř identické sestavy položek, jen jejich předmět nebude věnován mediaci, ale soudnímu řízení. Bude zajímavé sledovat, jaká struktura dotazníku nakonec v rámci EFA převládne a také, zda budou podobné položky moci tvořit př́ípadnou zkrácenou verzi jako u dotazníku DVSM. Vytvořené dotazníky pak budou moci sloužit pro další výzkumy věnované např́ílad rozdílnosti postojů různých aktérů soudního sporu ke spravedlnosti mediace a soudního řízení.

V rámci již běžícího projektu Vnímané spravedlnosti soudnich rozhodnutí podpořeného Grantovou agenturou Univerzity Karlovy se autoři chystají vytvořit ještě nástroj zaměřený př́mo na vnímání spravedlnosti konkrétních soudních rozhodnutí. V tuto chvíli se projekt nachází v prvním roce své realizace, kde se pozornost zaměřuje na ještě důkladnější rešerši především zahraničních a v mezidobí vydaných zdrojů věnovaných tématu soudní psychologie. $V$ dalších letech se autoři plánují zaměřit na ověření psychometrických kvalit výše uvedené metody. Bude vznikat v kooperaci se všemi dotčenými institucemi za účelem eliminace výše naznačených omezení diplomového „prototypu“, aby mohl sloužit jako kvalitní a široce využitelný měřicí nástroj vnímané spravedlnosti soudních rozhodnutí, včetně těch, $v$ jejichž průběhu bylo využito mediačního řízení.

\section{Závěr}

Snahou autorů tohoto textu bylo vypořádat se nejen s vlastní výzvou k většímu zapojení do výzkumu v oblasti soudní psychologie a vnímané spravedlnosti, ale také s nutností vytvoření nástrojů, které by $\mathrm{v}$ českých podmínkách mohly sloužit k výzkumným a později i praktickým účelům, jelikož zatím u nás vhodné metody z oblasti vnímané spravedlnosti neexistují. Pro výzkumné účely byl připraven dotazník postojů k mediaci DVSM i jeho zkrácené verze DVSM4 A DVSM8 s přijatelnými psychometrickými vlastnostmi. V nejbližší době budou autoři pracovat na dotazníku zjištujícím postoj ke spravedlnosti soudních řízení obecně a dále také na dotazníku ověrujícím vnímanou spravedlnost konkrétního soudního rozhodnutí. Existence metod odpovídající kvality ve výše uvedených oblastech autorům výhledově umožní realizovat výzkumy zaměřené na rozdílné vnímání spravedlnosti mediace a soudních řízení různými aktéry. Kromě toho je dlouhodobou vizí postupné zavádění využívání dotazníků vnímané spravedlnosti soudních rozhodnutí $\mathrm{v}$ praxi, tak jak je tomu zvykem $\mathrm{v}$ zahraničí.

Tento text byl vydán s finančni podporou grantu poskytnutého GA UK č. 392120 s názvem Vnimaná spravedlnost soudnich rozhodnutí: vývoj psychometricky kvalitního nástroje a výzkum vnímané spravedlnosti v rámci civilního ř́zení, včetně soudem nařizené mediace, řšeného na Filozofické fakultě Univerzity Karlovy. 
Použiti Dotazníku vnímané spravedlnosti mediace (DVSM), nebo jakýchkoli jeho částí podléhá predchozímu písemnému souhlasu autorů.

\section{LITERATURA}

Adams, J. S. (1963). Toward an Understanding of Inequity. Journal of Abnormal and Social Psychology, 67(5), $422-436$.

Adams, J. S. (1965). Inequity in Social Exchange. Advances in Experimental Social Psychology, 2, 267-299.

Ambrose, M. L., Seabright, M. A. \& Schminke, M. (2002). Sabotage in the Work-place: The Role of Organizational Injustice. Organizational Behaviorand Human Decision Processes, 89(1), 947-965.

Barling, J. \& Phillips, M. (1993). Interactional, Formal, and Distributive Justice in the Workplace: An Exploratory Study. Journal of Psychology, 127, 649-656.

Bies, R. J. (2005). Are Procedural Justice and Interactional Justice Conceptually Distinct? In J. Greenberg \& J. A. Colquitt (Ed.), Handbook of Organizational Justice (pp. 85-112), Lawrence Erlbaum Associates Publishers.

Bies, R. J., \& Moag, J. S. (1986). Interactional Justice: Communications Criteria of Fairness. In R. Lewitzki (Ed.), Research on Negotiation in Organizations (pp. 43-55), Jai Press.

Boukalová, H. \& Gillernová, I. (2020). Kapitoly z forenzní psychologie, Karolinum.

Cohen-Charash, Y. \& Spector, P. E. (2001). The Role of Justice in Organizations A Meta-analysis. Organizational Behavior and Human Decision Processes, 86(2), 278-321.

Colquitt, J. A. (2001). On the Dimensionality of Organizational Justice: A Construct Validation of a Measure. Journal of Applied Psychology, 86(3), 386-400.

Colquitt, J. A., Conlon, D. E., Wesson, M. J., Porter, C. \& Ng, K. Y. (2001). Justice at the Millennium: A Meta-analytic Review of 25 Years of Organizational Justice Research. Journal of Applied Psychology, $86(3), 425-445$.

Cropanzano, R. \& Ambrose, M. L. (2001). Procedural and Distributive Justice are More Similar Than You Think: A Monistic Perspective and a Research Agenda. In J. Greenberg \& R. Cropanzano (Eds.), Advances in Organizational justice (pp. 119-151), Stanford University Press.

Česká advokátní komora. (2005). Počet českých advokátů stale roste především diky absolventưm. https://www .cak.cz/scripts/detail.php?id=487.

Český statistický úr̆ad. (2011). Tab. 600 Obyvatelstvo podle ekonomické aktivity, pohlaví, věku a podle rodinného stavu. https://www.czso.cz/documents/10180/20534540/obcr600.pdf/f4b623af-697e-4d04 $-9040-7 \mathrm{c} 396 \mathrm{e} 101 \mathrm{~d} 93$ ? version=1.0.

Čírtková, L. (2004). Forenzní psychologie. Aleš Čeněk.

De Girolamo, D. (2019). The Mediation Process: Challenges to Neutrality and the Delivery of Procedural Justice. Oxford Journal of Legal Studies, 39(4), 834-855.

Deutsch, M. (1975). Equity, Equality, and Need: What Determines Which Value Will Be Used as the Basis of Distributive Justice? Journal of Social Issues, 31(3), 137-149.

Deutsch, M. (1985). Distributive Justice: A Social-Psychological Perspective. Yale University Press.

Di̊vodová zpráva k zákonu o mediaci. (2011). http://forarb.com/wp-content/uploads/2011/11/zakon-o-mediaci -duvodova-zprava.pdf.

Emery, R. E., Laumann-Billings, L., Waldron, M., C., Sbarra, D., A. \& Dillon, P. (2001). Child Custody Mediation and Litigation: Custody, Contact, and Coparenting 12 Years After Initial Dispute Resolution. Journal of Consulting and Clinical Psychology, 69(2), 323-332.

Greenberg, J. (1987). A Taxonomy of Organizational Justice Theories. Academy of Management Review, 12(1), $9-22$.

Greenberg, J. (1988). Cultivating an Image of Justice: Looking Fair on the Job. The Academy of Management EXECUTIVE, 2(2), 155-157.

Greenberg, J. (1990). Organizational Justice: Yesterday, Today, and Tomorrow. Journal of Management, 16(2), 399-432.

Greenberg, J. (1993). The Social Side of Fairness: Interpersonal and Informational Classes of Organizational Justice. In R. Cropanzano (Ed.), Justice in the workplace: Approaching fairness in human resource management (pp.79-103). Erlbaum. 
Hollander-Blumoff, R. (2017). Formation of Procedural Justice Judgments in Legal Negotiation. Group Decision and Negotiation, 26(1), 19-43.

Hollander-Blumoff, R. \& Tyler, T. R. (2008). Procedural Justice in Negotiation: Procedural Fairness, Outcome Acceptance, and Integrative Potential. Law \& Social Inquiry, 33(2), 473-500.

Homans, G. C. (1961). Social Behavior: its Elementary Forms. Harcourt, Brace \& World.

Jaroš, J. (2019). Postoje některých zástupců veřejnosti k mediaci se zaměrením na férovost a vnímanou spravedlnost [Diplomová práce]. Univerzita Karlova.

Kahneman, D. (2013). Thinking, fast and slow. Farrar, Straus and Giroux.

Kernan, M. C. \& Hanges, P. J. (2002). Survivor Reactions to Reorganization: Antecedents and Consequences of Procedural, Interpersonal, and Informational Justice. Journal of Applied Psychology, 87(5), 916-928.

Kitzmann, K., M., \& Emery, R. E. (1993). Procedural Justice and Parents' Satisfaction in a Field Study of Child Custody Dispute Resolution. Law and Human Behavior, 17(5), 553-567.

Lind, E. A. \& Tyler, T. R. (1988). The Social Psychology of Procedural Justice. Plenum.

Lind, E. A., Kulik, C. T., Ambrose, M. \& de Vera Park, M. V. (1993). Individual and Corporate Dispute Resolution: Using Procedural Fairness as a Decision Heuristic. Administrative Science Quarterly, 38(2), $224-251$.

Leventhal, G. S. (1976). The Distribution of Rewards and Resources in Groups and Organizations. Advances in Experimental Social Psychology, 9, 91-131.

Leventhal, G. S. (1980). What Should Be Done with Equity Theory? New Approaches to the Study of Fairness in Social Relationships. In K. J. Gergen (Ed.), Social exchange: Advances in theory and research (pp. 27-55). Plenum.

Maine Statistical Analysis Center. (2017). 2017 Court Access \& Fairness Survey Resport. http://justiceresearch .usm.maine.edu/files/2018/05/2017_Court_Access_and_Fairness_Survey_Report-1tpod2e.pdf.

Meares, T. L., Tyler, T. R. \& Gardener, J. (2016). Lawful or Fair?: How Cops and Laypeople Perceive Good Policing. Journal of Criminology and Criminal Law, 105(2), 297-344.

Mikula, G., Petrik, B. \& Tanzer, N. (1990). What People Regard as Unjust: Types and Structures of Everyday Experiences of Injustice. European Journal of Social Psychology, 20, 133-149.

Ministerstvo spravedlnosti ČR. (2018). České soudnictví 2017: Výroční statistická zpráva. https://www.justice .cz/documents/12681/719244/2017_vyrocni_stat_zprava.pdf/27ba4524-49cb-4744-b834-2c6812f13e5d.

Ministerstvo spravedlnosti ČR. (2019). Seznam mediátorů. http://mediatori.justice.cz/MediatorPublic/Public /FR003_ZverejneniVybranychUdaju.aspx.

National Center for State Courts. (2005). Access and Fairness. http://www.courtools.org/ /media/Microsites /Files/CourTools/CourTools\%20Measure\%201\%20-\%20Access $\% 20$ and $\% 20$ Fairness.ashx.

Niehoff, B. P. \& Moorman, R. H. (1993). Justice as a Mediator of the Relationship Between Methods of Monitoring and Organizational Citizenship Behaviors. Academy of Management Journal, 36(3), 527-556.

Polišenská, V. A. (2019a). Forenzní psychologie: teorie a praxe. Vysoká škola finanční a správní.

Polišenská, V. A. (2019b). Forenzní psychologie v české psychologické literatuře - náhled do historie do začátku druhé světové války. E-psychologie, 13(1), 32-47.

Pruitt, D. G., McGillicuddy, N. B., Welton, G. L., \& Castrianno, L. M. (1993). Long-Term Success in Mediation. Law and Human Behavior, 17(3), 313-330.

Rottman, D. B., \& Tyler, T.R. (2014). Thinking about Judges and Judicial Performance. Onati Socio-legal Series, 4(5), 1046-1070.

Sivasubramaniam, D. \& Heuer, L. (2007). Decision Makers and Decision Recipients: Understanding Disparities in the Meaning of Fairness. Court Review, 44(1/2), 62-70.

Shapiro, D. L., Buttner, E. H. \& Barry, B. (1994). Explanations: What Factors Enhance their Perceived Adequacy? Organizational Behavior and Human Decision Processes, 58(3), 346-368.

Sweeney, P. D. \& McFarlin, D. B. (1993). Workers' Evaluations of the Ends and the "Means": An Examination of Four Models of Distributive and Procedural justice. Organizational Behavior and Human Decision Processes, 55(1), 23-40.

Thibaut, J. \& Walker, L. (1975). Procedural Justice: A Psychological Analysis. Lawrence Erlbaum Associates.

Thaler, R. H. \& Sunstein, C. R. (2010). Nudge (štouch): Jak postrčit lidi k lepšímu rozhodování o zdraví, majektu a štěstí. Kniha Zlín.

Trinkner, R., Tyler, T. R. \& Goff, P. A. (2016). Justice From Within: The Relations Between a Procedurally Just Organizational Climate and Police Organizational Efficiency, Endorsement of Democratic Policing, and Officer Well-being. Psychology, Public Policy and Law, 22, 158-172. 
Tyler, T. R. (1989). The Psychology of Procedural Justice: A Test of the Group-value Model. Journal of Personality and Social Psychology, 57(5), 830-838.

Tyler, T. R. (2000). Social Justice: Outcome and Procedure. International Journal of Psychology, 35(2), 117-125. Tyler, T. R. (2007). Procedural Justice and the Courts. Court Review, 44(1/2), 26-31.

Tyler, T. R. (2017a). Can the Police Enhance Their Popular Legitimacy Through Their Conduct?: Using Empirical Research to Inform Law. University of Illinois law review, 2017(5), 1971-2008.

Tyler, T. R. (2017b). Procedural Justice and Policing: A Rush to Judgment? Annual Review of Law and Social Science, 13(1), 29-53.

Tyler, T. R., Goff, P. \& MacCoun, R. (2015). The Impact of Psychological Science on Policing in the United States: Procedural Justice, Legitimacy, and Effective Law Enforcement. Psychological Science in the Public Interest, 16(3), 75-109.

Mgr et Mgr. Jan Jaroš, Univerzita Karlova, Filozofická fakulta, katedra psychologie, e-mailJan.Jaros@ff.cuni.cz

PhDr. Eva Höschlová, Ph.D., Univerzita Karlova, Filozofická fakulta, katedra psychologie, e-mailEva.Hoschlova@ff.cuni.cz 